The Effect of Stretching on the Thermal Conductivity of Wires

This content has been downloaded from IOPscience. Please scroll down to see the full text. 1916 Proc. Phys. Soc. London 29195

(http://iopscience.iop.org/1478-7814/29/1/316)

View the table of contents for this issue, or go to the journal homepage for more

Download details:

IP Address: 132.174.255.116

This content was downloaded on 02/10/2015 at 04:12

Please note that terms and conditions apply. 
XIV. The Effect of Stretching on the Thermal Conductivity of Wires. By A. Johnstone, B.SC.

Received March 7, 1917.

Communicated by Prof. C. H. Lees, F.R.S.

Outuine of Method Used.

1. Most observers, in determining the thermal conductivity of substances which conduct heat readily, have found it advisable to use the material in the form of wire and to let the heat flow along the axis. This method was adopted in the present experiments. The method is simplified if the heat flows from the centre of the wire to the two ends, which are kept at a constant temperature. In the following experiments the wire was surrounded by a vessel to ensure this, heat was - upplied to the centre of the wire by passing a current of electricity through a manganin coil wound on the wire, and the temperature difference between two points on the same side of the centre was ascertained by means of two platinum coils also wound on the wire.

\section{The Apparatus.}

2. The wire to be tested $A A$, (Fig. 1) was fixed at each end between the jaws of screw clamps, $B$, joined to the brass cylinders, through which water could be circulated. To one clamp was attached a rod, $\%$, passing through a framework, so that the iension could be applied by a nut working on a thread, ' ' ' and to the other was attached a spring balance, $K$, by which the tension was measured.

The heating coil $H_{t}$ was made from $14 \mathrm{cms}$. of No. 40 manyanin wire closely wound on cylindrical sleeves of micanite, wh ch could just slide on to the wire; $0.5 \mathrm{~cm}$. of the wire was left unwound at each end, and to these ends were soldered covered copper leads of No. 30 gauge. The platinums thermometers $\left(H, C, J^{\prime}\right)$ used were made from No. 40 single silkcovered platinum wire each of $35 \mathrm{cms}$. length, wound like the heating coil and having similar leads. This gave them a resistance of about 3 ohms at ordinary temperatures. The heating coil was placed at the centre of the wire under examination which was about $16 \mathrm{cms}$. long; one platinum thermometer was placed near to it, and the other near one of the clamps. For purposes of reference the former will be called the " hot coil" and the other the "cold coil." To support the leads from the 
coils against breakage, each coil was tied by silk threads to a light wooden strip which it touched at two points and to which the leads were fixed. The coils were kept at a constant dis-

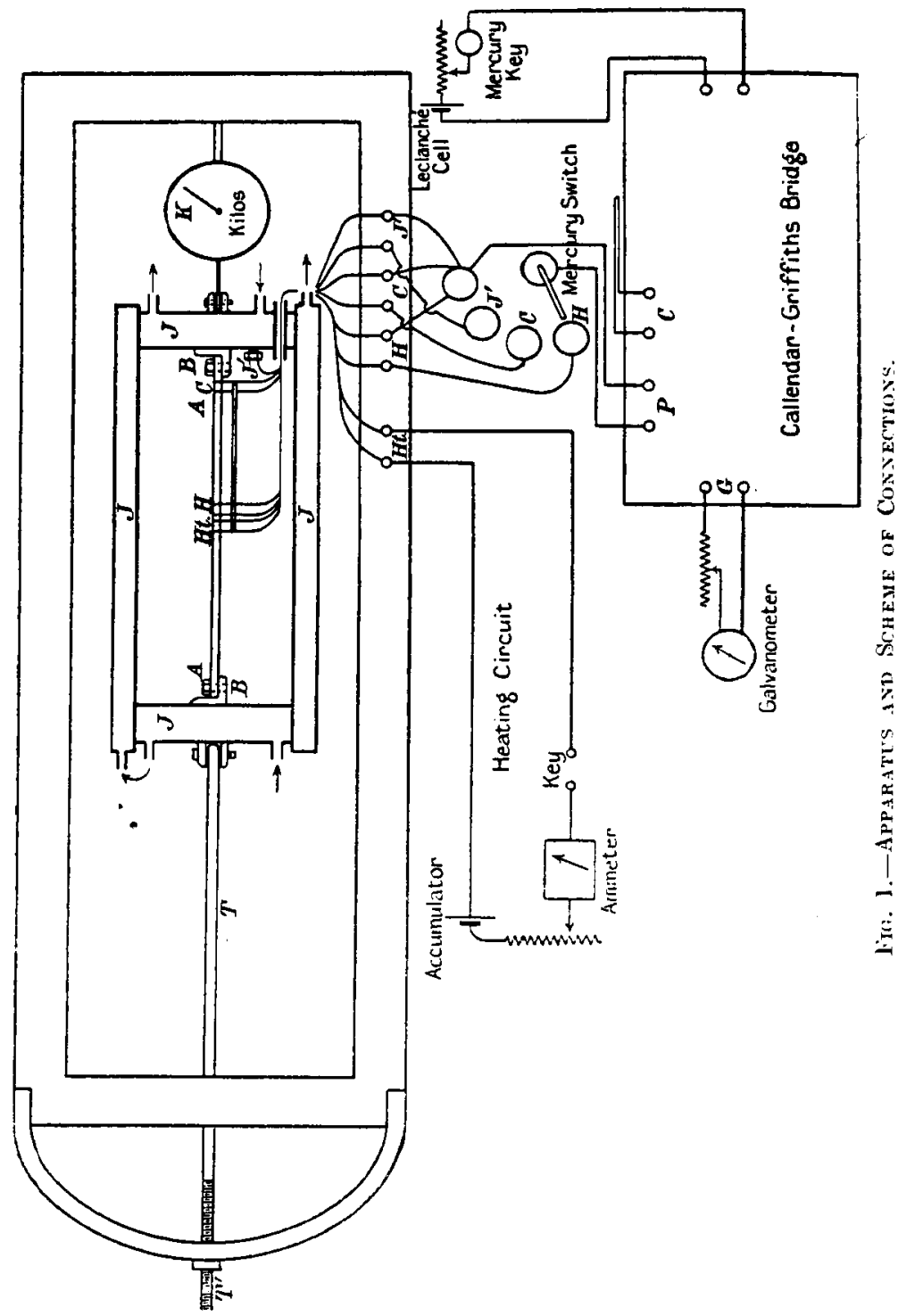

tance apart by a cross strip of mica and were strengthened by a coating of shellac to prevent collapse during subsequent removal. The insulated leads from the coils were passed through 
a brass tube in one of the end clamps to mercury cups in the wood frame, and the wire and end pieces were surrounded by a water jacket. Inside and touching the jacket was a supplementary platinum coil to enable changes in the jacket temperature to be detected.

The resistances of the coils were determined by means of a Callendar-Griffiths bridge, which was read in ohms to the fourth decimal place. For the galvanometer used a deflection of $1 \mathrm{~mm}$. on the scale represented a difference of $0.0002 \mathrm{ohm}$, and for the coils used this would represent a temperature difference of about $0.01^{\circ} \mathrm{C}$. For the conditions of the experiments performed this would enable a difference in the conductivity of 0.05 per cent. to be detected. The current to the heating coil was supplied by an accumulator and was regulated. by an adjustable resistance. The current for the bridge was supplied by a Leclanché cell in series with an adjustable resistance. Each of the platinum coils could be connected in turn with the bridge at $P$ through the mercury key as shown in the diagram.

\section{Theory of The Method Used.}

3 . If a thin rod of uniform cross section is entirely surrounded by air in a vessel kept at constant temperature, while heat is supplied to it near one end and the other is kept in good thermal contact with the wall of the vessel, then *

$$
v=\frac{Q}{(p h q k)^{!}} \cdot \sinh \left(\frac{p h}{q k}\right)^{\frac{1}{2}} x / \cosh \left(\frac{p h}{q k}\right)^{!} x_{C} \quad .
$$

where $v$ is excess of temperature of rod at the cross section $x \mathrm{~cm}$. from the end in contact with the vessel, over that of the vessel, $p$ is the perimeter, $q$ is the area of cross section, $h$ the emissivity, $k$ the thermal conductivity of the rod, and $Q$ is the amount of heat per second crossing the section at any point $x_{C}$

If the heat is supplied at a uniform rate per centimetre to the surface of the rod between $x_{C}$ and the free end, the mean temperature of the surface between $x_{c}$ and the end may be taken as $v_{C^{\prime}}$, the temperature which would be observed at a point $x_{C^{\prime}}$, dividing the distance between $x_{c}$ and the free end in the ratio $1: 2$, if the equation (1) held throughout the heated

* See Lees, Bakerian Lecture, "Phil. Trans." Roy. Soc. A 208, pp. 38L. $443(1908)$. 
part of the rod. If $s$ is the area of the surface of the rod beyond $x_{C}$ and $H$ is the total heat supplied to the rod, then

$$
Q=H-h . s v_{C^{\prime}} \text {. . . . . . . }
$$

If the temperature excesses $v_{A}$ and $v_{B}$ of the rod over the air at two sections $x_{A}$ and $x_{n}$ are observed then,

$$
k=\left\{\begin{array}{c}
H\left(x_{A} S_{A}-x_{B} S_{B}\right) \\
v_{A}-v_{B}
\end{array}-h s x_{\sigma^{\prime}} S_{C^{\prime}}\right\} / q \cosh \alpha x_{C} .
$$

where $\alpha$ is written for $(p h / q k)^{\frac{1}{2}}$ and $S_{A}$ for $\sinh \alpha x_{A} / \alpha x_{A}$, \&c.

From equation (3) $k$ may be calculated with sufficient accuracy by taking, $\sinh \alpha x / \alpha x=\cosh \alpha x=1$ approximately, and neglecting the term $\left(\frac{h s x_{C^{\prime}}}{q}\right)$, which, for the experiments described, introduces an error in $k$ of approximately 0.003 per cent.

We thus get

$$
k=\frac{H}{q} \cdot \frac{x_{A}-x_{B}}{v_{A}-v_{i /}} . . \quad \text {. . . . }
$$

Since for any one experiment $H, q, x_{A}-x_{B}$, were constant we may take $k$ proportional to

$$
\left(v_{A}-v_{B}\right)^{-1} \text {. . . . . . . . . }
$$

If $R_{1}$ is the resistance of the platinum thermometer used to determine $v_{s}$, and $r_{1}$ is that for $v_{B}$ when both are at the jacket temperature, and if $\boldsymbol{R}_{2}$ and $r_{2}$ are the corresponding values when a temperature difference exists'; then it may be shown that

where $B$ is a constant.

$$
v_{A}-v_{B}=\frac{1}{B}\left(\begin{array}{l}
R_{2} \\
R_{1}-r_{2}
\end{array}\right) \text {. }
$$

Hence for any experiment we may take

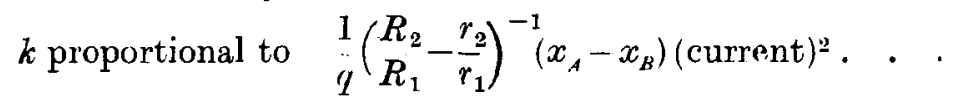

In order to detect inconsistencies in readings during an experiment a method for finding $v_{d}-v_{B}$ approximately was also used.

\section{Method of Experimenting. .}

4. When taking a resistance reading for any of the coils, to avoid thermo-effects the galvanometer was kept in circuit and the deflection of the galvanometer noted when the Leclanche cell was connected to the bridge. At the beginning of an experiment tap water was circulated through the jacket and the resistance of the jacket coil was read at intervals. After about 
45 minutes the temperatures usually became steady. The resistances of the "hot" and "cold" coils were then read. Then a suitable current was sent through the heating coil. After about 30 minutes the resistances of the coils had become steady and were again read. Owing to slight variations in the jacket temperature it was seldom possible to repeat these readings and obtain exactly the same values. Consequently an attempt was made to read the resistances of the two coils with as small a time difference as possible. A number of such double readings was taken and the mean temperature difference of the coil calculated The resistance of the jacket coil was read at intervals to detect abnormal changes. The wire was then stretched by a force about 0.7 of the elastic limit and the resistances of the coils read again. The stretching force was then removed and readings again taken. The temperature difference between the hot and cold coils varied between $10^{\circ} \mathrm{C}$. and $20^{\circ} \mathrm{C}$.

The wires tested were all (except the nickel one, which was No. 16 gauge) of No. 14 gauge. When new wires were used the results for successive experiments were not consistent with each other: until about the third experiment, owing probably to initial stresses in the wires; and the results were more consistent during the summer months, when the temperature of the jacket water was not affected by the heating apparatus. The effect of the stretching on the dimensions of the wire is neglected, as its influence on the conductivity is too small.

\section{Comments on the Results.}

For all the wires used, stretching produced a slight increase in thermal conductivity. Although difficulty was experienced in getting results which were consistent throughout, those obtained when conditions were most satisfactory show an increase of about 0.5 per cent. for a tension about 0.7 of the elastic limit. A few experiments apparently showed a decrease in conductivity o the order 0.1 per cent. w th stretching, but in these cases the readings were always unsteady and unsatisfactory. In all cases when readings were steady an increase was observed. Several attempts were made to determine the change in conductivity for smaller tensions, and the results seem to indicate that the change is not appreciable until the tension approaches the elastic limit. After the tension was withdrawn the conductivity returned approximately to its original value, although in most cases the value was slightly in excess 
Observations and Results.

\begin{tabular}{|c|c|c|c|c|c|c|c|}
\hline \multirow{3}{*}{$\begin{array}{c}\text { Date. } \\
1914 .\end{array}$} & \multicolumn{7}{|c|}{ Copper Wire, No. 14 Gauge. $x_{A}-x_{B}=4.25 \mathrm{~cm}$. } \\
\hline & \multirow{2}{*}{$\begin{array}{c}\text { Duration } \\
\text { of experi- } \\
\text { ments. } \\
\text { Hrs. }\end{array}$} & \multicolumn{2}{|c|}{ Tensions. } & \multirow{2}{*}{$\begin{array}{c}\left\{\frac{R_{2}}{R_{1}}-\frac{r_{2}}{r_{2}}\right\}^{-1} \\
\text { proportional } \\
\text { to } k\end{array}$} & \multirow{2}{*}{$\begin{array}{c}\text { Per. } \\
\text { centage } \\
\text { increase } \\
\text { in } k .\end{array}$} & \multirow{2}{*}{$\begin{array}{l}\text { Current } \\
\text { used to } \\
\text { give H. } \\
\text { Amps. } \\
\end{array}$} & \multirow{2}{*}{$\begin{array}{l}\left\{\frac{R_{2}}{R_{1}}-r_{2}\right)^{-1} f^{-1} \\
\times\left(\text { curre }_{t}\right)^{2} \\
\times\left(x_{A}-x_{B}\right) .\end{array}$} \\
\hline & & Kilos. & $\mathrm{Kilos} / \mathrm{cm} .^{2}$ & & & & \\
\hline July Sth... & 4 & $\begin{array}{r}0 \\
15 \\
0\end{array}$ & 463 & $\begin{array}{l}26.88 \\
26.98 \\
26.90\end{array}$ & 0.37 & 0.3 & $\begin{array}{l}10 \cdot 28 \\
10 \cdot 32 \\
10 \cdot 29\end{array}$ \\
\hline Sept. 8th. & 5 & $\begin{array}{r}0 \\
10 \\
0\end{array}$ & 309 & $\begin{array}{l}16 \cdot 03 \\
16 \cdot 12 \\
16 \cdot 09\end{array}$ & 0.56 & 0.4 & $\begin{array}{l}11.03 \\
11.09 \\
11.07\end{array}$ \\
\hline Sept, 9th. & 6 & $\begin{array}{r}0 \\
10 \\
0\end{array}$ & 309 & $\begin{array}{l}15 \cdot 82 \\
15 \cdot 84 \\
15 \cdot 82\end{array}$ & $0 \cdot 13$ & $0 \cdot 4$ & $\begin{array}{l}10.88 \\
10.90 \\
10.88\end{array}$ \\
\hline Sept. 10th. & 5 & $\begin{array}{r}0 \\
10 \\
0\end{array}$ & 309 & $\begin{array}{l}27 \cdot 10 \\
27 \cdot 29 \\
27 \cdot 12\end{array}$ & $0 \cdot 70$ & $0 \cdot 3$ & $\begin{array}{l}10.37 \\
10 \cdot 44 \\
10.38\end{array}$ \\
\hline Sept. llth. & 5 & $\begin{array}{r}0 \\
10 \\
0\end{array}$ & 309 & $\begin{array}{l}27 \cdot 03 \\
27 \cdot 25 \\
27 \cdot 10\end{array}$ & 0.81 & $0 \cdot 3$ & $\begin{array}{l}10 \cdot 34 \\
10 \cdot 42 \\
10 \cdot 37\end{array}$ \\
\hline \multicolumn{8}{|c|}{ Steel Wire, No. 14 Gauge. $x_{A}-x_{B}=4.45 \mathrm{~cm}$. } \\
\hline Oct. 2 lst & $4 \frac{1}{2}$ & $\begin{array}{r}0 \\
40 \\
0\end{array}$ & 1,235 & $\begin{array}{l}16 \cdot 66 \\
16 \cdot 74 \\
16 \cdot 69\end{array}$ & 0.48 & 0.2 & $\begin{array}{l}2 \cdot 966 \\
2 \cdot 980 \\
2 \cdot 971\end{array}$ \\
\hline Oct. $28 \mathrm{th}$ & $4 \frac{1}{2}$ & $\begin{array}{r}0 \\
40 \\
0\end{array}$ & 1,235 & $\begin{array}{l}16 \cdot 57 \\
16 \cdot 77 \\
16 \cdot 66\end{array}$ & 1.21 & 0.2 & $\begin{array}{l}2 \cdot(44 !) \\
2 \cdot 98.1 \\
2 \cdot(961)\end{array}$ \\
\hline Nor: 4th. & $4 \frac{1}{2}$ & $\begin{array}{r}0 \\
40 \\
0\end{array}$ & 1,235 & $\begin{array}{l}16 \cdot 36 \\
16 \cdot 46 \\
16 \cdot 36\end{array}$ & $0 \cdot 61$ & 0.2 & $\begin{array}{l}2 \cdot 912 \\
2 \cdot 912 ! \\
2 \cdot(112 \\
\end{array}$ \\
\hline 198. & \multicolumn{7}{|c|}{ Nickel Wire, No. 16 Gauge. $x_{A}-x_{B}=4.75 \mathrm{~cm}$. } \\
\hline June $23 \mathrm{rd}$ & 4 & $\begin{array}{r}0 \\
15 \\
0\end{array}$ & 723 & $\begin{array}{l}25 \cdot 46 \\
25 \cdot 51 \\
25 \cdot 21\end{array}$ & 0.20 & $0 \cdot 16$ & $\begin{array}{l}3 \cdot 0695 \\
3 \cdot 101 \\
3 \cdot 066\end{array}$ \\
\hline June $2+$ th. & 4 & $\begin{array}{r}0 \\
20 \\
0\end{array}$ & 964 & $\begin{array}{l}29 \cdot 33 \\
29 \cdot 40 \\
29 \cdot 35\end{array}$ & 0.24 & 0.16 & $\begin{array}{l}3.567 \\
3 \cdot 575 \\
3 \cdot 5169\end{array}$ \\
\hline Tune 30th. & $3 \frac{1}{2}$ & $\begin{array}{r}0 \\
20 \\
0\end{array}$ & 964 & $\begin{array}{l}25 \cdot 51 \\
25 \cdot 66 \\
25 \cdot 50\end{array}$ & 0.59 & 0.16 & $\begin{array}{l}3 \cdot 104 \\
3 \cdot 120 \\
3 \cdot 100\end{array}$ \\
\hline
\end{tabular}


Aluminium Wire, No. 14 Gauge. $x_{4}-x_{B}=4.55 \mathrm{~cm}$.

\begin{tabular}{|c|c|c|c|c|c|c|c|}
\hline \multirow{2}{*}{$\begin{array}{l}\text { Date. } \\
1914 .\end{array}$} & \multirow{2}{*}{$\begin{array}{c}\text { Duration } \\
\text { of experi- } \\
\text { ments. } \\
\text { Hrs. }\end{array}$} & \multicolumn{2}{|c|}{ Tensions. } & \multirow{2}{*}{$\begin{array}{l}\left\{\frac{R_{2}}{R_{1}}-\frac{r_{2}}{r_{1}}\right\}^{-1} \\
\text { proportional } \\
\text { to } k\end{array}$} & \multirow{2}{*}{$\begin{array}{l}\text { Per. } \\
\text { centage } \\
\text { increase } \\
\text { in } l:\end{array}$} & \multirow{2}{*}{$\begin{array}{c}\text { Current } \\
\text { used to } \\
\text { give } H . \\
\text { Amps. }\end{array}$} & \multirow{2}{*}{$\begin{array}{l}\left\{\frac{R_{2}}{R_{1}}-\frac{r_{8}}{r_{1}}\right\}^{-1} \\
\times(\text { current })^{2} \\
\times\left(x_{A}-x_{B}\right)\end{array}$} \\
\hline & & Kilos. & $\mathrm{Kilos} / \mathrm{cm} .^{2}$ & & & & \\
\hline Nov. 18th. & $4 \frac{1}{2}$ & $\begin{array}{r}0 \\
15 \\
0\end{array}$ & 463 & $\begin{array}{l}14 \cdot 64 \\
14 \cdot 68 \\
14 \cdot 68\end{array}$ & 0.27 & 0.3 & $\begin{array}{l}5.995 \\
6.012 \\
6.012\end{array}$ \\
\hline Nov, 25th. & $4 \frac{1}{2}$ & $\begin{array}{r}0 \\
15 \\
0\end{array}$ & 463 & $\begin{array}{l}18 \cdot 66 \\
18 \cdot 75 \\
18 \cdot 66\end{array}$ & 0.48 & 0.26 & $\begin{array}{l}5 \cdot 740 \\
5 \cdot 768 \\
5 \cdot 740\end{array}$ \\
\hline Dec. 2 nd... & 3 & $\begin{array}{r}0 \\
15 \\
0\end{array}$ & 463 & $\begin{array}{l}18 \cdot 94 \\
19 \cdot 18 \\
18 \cdot 79\end{array}$ & 1.27 & 0.26 & $\begin{array}{l}5 \cdot 826 \\
5 \cdot 899 \\
5 \cdot 780\end{array}$ \\
\hline
\end{tabular}

Brass Wire, No.14 Gauge. $x_{A}-x_{B}=4.6 \mathrm{~cm}$.

\begin{tabular}{|c|c|c|c|c|c|c|c|}
\hline Dec, 16th. & $4 t$ & $\begin{array}{r}0 \\
15 \\
0\end{array}$ & 463 & $\begin{array}{l}15 \cdot 51 \\
15 \cdot 55 \\
15 \cdot 44\end{array}$ & 0.20 & 0.2 & $\begin{array}{l}2 \cdot 854 \\
2 \cdot 861 \\
2 \cdot 841\end{array}$ \\
\hline $\begin{array}{c}\text { Jan. 27th, } \\
1915\end{array}$ & 4 & $\begin{array}{r}0 \\
15 \\
0\end{array}$ & 463 & $\begin{array}{l}15 \cdot 20 \\
15 \cdot 25 \\
15 \cdot 19\end{array}$ & 0.33 & $0 \cdot 2$ & $\begin{array}{l}2.797 \\
2.805 \\
2.795\end{array}$ \\
\hline
\end{tabular}

1915.

Zinc Wire, No. 4 Gauge. $x_{A}-x_{B}=4.65 \mathrm{~cm}$.

\begin{tabular}{|c|c|c|c|c|c|c|c|}
\hline Mar. 3rd... & 4 & $\begin{array}{r}0 \\
15 \\
0\end{array}$ & 463 & $\begin{array}{l}21 \cdot 82 \\
21 \cdot 90 \\
21 \cdot 72\end{array}$ & 0.37 & 0.2 & $\begin{array}{l}4.059 \\
4.072 \\
4.040\end{array}$ \\
\hline May .jth... & $4 \frac{1}{2}$ & $\begin{array}{r}0 \\
15 \\
0\end{array}$ & 463 & $\begin{array}{l}21 \cdot 17 \\
21 \cdot 23 \\
21 \cdot 21\end{array}$ & 0.28 & 0.2 & $\begin{array}{l}3.938 \\
3.950 \\
3.945\end{array}$ \\
\hline May 12th. & 4 & $\begin{array}{r}0 \\
15 \\
0\end{array}$ & 463 & $\begin{array}{r}21.93 \\
22.03 \\
\text { unsatis- } \\
\text { factory }\end{array}$ & 0.40 & 0.2 & $\begin{array}{r}4.079 \\
4.098 \\
\text { unsatis- } \\
\text { factory }\end{array}$ \\
\hline May 19th & $3 \frac{1}{2}$ & $\begin{array}{r}0 \\
15 \\
0\end{array}$ & 463 & $\begin{array}{l}22 \cdot 52 \\
22 \cdot 68 \\
22 \cdot 62\end{array}$ & 0.71 & 0.2 & $\begin{array}{l}4 \cdot 189 \\
4 \cdot 218 \\
4 \cdot 207\end{array}$ \\
\hline May 26th. & 4 & $\begin{array}{r}0 \\
15 \\
0\end{array}$ & 463 & $\begin{array}{l}22 \cdot 93 \\
22 \cdot 96 \\
22 \cdot 94\end{array}$ & 0.10 & 0.2 & $\begin{array}{l}4 \cdot 265 \\
4 \cdot 271 \\
4 \cdot 267\end{array}$ \\
\hline
\end{tabular}


of the original value. The numbers quoted for $k$ in the results. are values proportional to the thermal conductivity.

The relative conductivities calculated from the values of the heating currents and of $x_{A}-x_{B}$, on the assumption that the conductivity of copper is 0.90 are : copper 0.90 , steel 0.25 , nickel 0.18 , aluminium 0.50 , brass 0.24 , zinc 0.35 , whose relation is of the right order.

The experiments described in this Paper were carried out at the suggestion of Prof. Lees, to whom I am indebted for the general design of the apparatus used and for valuable suggestions during the oourse of the work.

\section{ABSTRACT.}

In the experiments carried out, the wire to be tested was fixed at each end between the jaws of screw clamps joined to brass cylinders, through which water could be circulated. Attached to one clamp was a rod passing through a framework, enabling tension to be applied by a nut working on a thread.

Heat was supplied to the centre of the wire by passing a current of electricity through a manganin coil wound on the wire, and the temperature difference between two points on the same side of the centre was ascertained by two platinum coils, also wound on the wire.

The resistances of the coils were determined by means of a Callendar-Griffiths bridge, enabling a temperature difference of $0.01^{\circ} \mathrm{C}$. to be read, and making it possible to detect a difference in conductivity of 0.05 per cent. If $R_{1}$ is the resistance of the platinum thermometer nearer the heating coil, and $r_{1}$ is that of the other platinum coil when both are at the jacket temperature; and if $R_{2}$ and $r_{2}$ are corresponding values when a temperature difference exists. then it may be shown that the conductivity

$$
K \text { is proportional to }\left(\frac{R_{2}}{R_{1}}-\frac{r_{2}}{r_{1}}\right)^{-1} \text {. }
$$

For all the wires used (copper, steel, nickel, aluminium, brass, zine), stretching produced a slight increase in thermal conductivity: The most satisfactory experiments showed an increase of about 0.5 per cent. for a tension of about $0 \cdot \mathbf{7}$ of the elastic limit.

After the tension was withdrawn the conductivity returned approximately to its original value.

\section{DISCUSSION.}

Mr. F. E. Surth suggested that it would have been of interest if the author had made simultaneous observations of electrical conductivity on the same apparatus. Had any experiments been made on liquids, such as mercury, for example?

Prof. Boys asked if the coefficient would be reversed if compression were applied instead of extension. He realised there would be some practical difficulties in making the experiments.

Prof. LEES, in reply, said that there would have been electrical measurements included in the Paper but for the author's absence in the Armr. He thought compression measurements could be made, though they hat not so far been carried out. 